\title{
EFFECTS OF IRRIGATION SYSTEMS AND WATER STRESS WITH LOW WATER AND SOIL QUALITY ON QUINOA YIELD IN ARID CONDITIONS
}

\section{H. Mostafa ${ }^{1 \&^{*}}$ and A. Farag ${ }^{2}$}

${ }^{1}$ Assoc. Prof. of Ag. Eng., Fac. of Ag., Benha Uni., Qalyobia, Egypt.

${ }^{2}$ Assoc. Prof. of Ag. Eng., Fac. of Ag., Benha Uni., Qalyobia, Egypt.

* harby.mostafa@fagr.bu.edu.eg

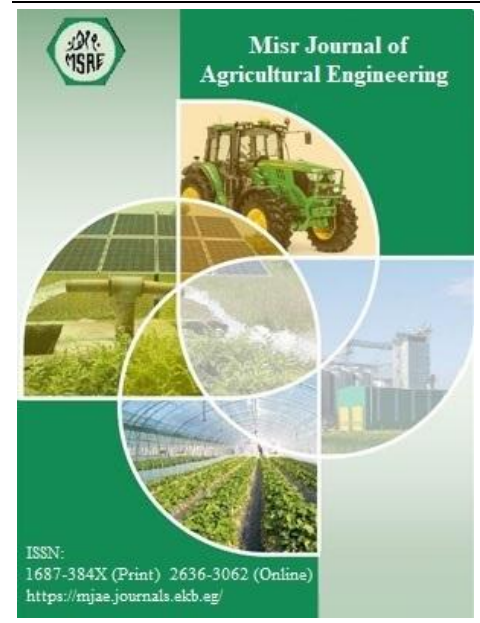

(C) Misr J. Ag. Eng. (MJAE)

\section{Keywords:}

Ground water, soil salinity, water stress, productivity.

\section{ABSTRACT}

Due to the water scarcity in the recent period in dry areas, as is the case in Egypt, so some means have to be used to save water as the use of irrigation systems under water stress, the use of lowquality water, as well as plants that tolerate these conditions. Two field experiments were conducted on a clayey soil with low quality (3.1 dSm-1) in southern Nile Delta of Egypt for evaluating the influence of low quality soil and water on quinoa productivity (initial experiment) and the effects of surface drip (SDI) and subsurface drip (SSDI) irrigation methods with three irrigation regimes $(100 \%, 80 \%$ and $60 \%$ of irrigation requirements) and humic acid (0 and $50 \mathrm{mgl}-1)$ on soil moisture and salinity, yield and water use efficiency of quinoa (main experiment). The initial experiment was done on pots to measure the effect of water quality (fresh water (0.45 dSm-1), ground water (2.8 dSm-1) and saline water (5 and $7 \mathrm{dSm}-1)$ ) on productivity. Regarding to results, the yield was significantly decreased by using saline water (5 and $7 \mathrm{dSm}-1$ ), while there were no differences between fresh and ground water. The results of the main experiment indicate that using ground water to irrigate quinoa with SSDI, 80\% water stress and $50 \mathrm{mgl}-1$ humic acid improved soil salinity, $\mathrm{pH}$ and moisture content. These favorable conditions of the improved soil reflected on the vegetative growth parameters of quinoa and showed significant increases in seed yield $(4.17 \mathrm{Mg}$ ha-1) and water productivity (3.78 $\mathrm{kg} \mathrm{m}-3)$.

\section{INTRODUCTION}

I rrigation is considered playing a significant role in raising agricultural productivity. Climate change effects present an additional threat to the limited freshwater supplies, especially in arid and semi-arid regions. The high demand for water supplies in the dry regions forced farmers to use water of inferior quality for irrigation including groundwater. The use of these low irrigation qualities depends on the crop, restricted irrigation, soil characteristics, climate, water distribution network, plant growth stages, and time consumption of the irrigation water applied in the growing season (Ahmed $\boldsymbol{e t}$ al., 2018). By using less water with sufficient irrigation techniques for the shortfall, a high yield can be achieved. Another alternative 
approach could be to irrigate with low -quality water such as salt or waste water instead of fresh water (Yazar and ubiquitous Kaya, 2014). In these circumstances, it requires effective management tools for limited soil and water resources are required to increase crop production in a safe and pleasant environment to increase the population (Iqbal, 2015). On the other hand, agricultural development is rapidly confronted with environmental constraints such as drought, salinity, and climate change adverse effects. Therefore, it has become necessary to use restricted or low-quality water and soil resources effectively and to include new stress-tolerant crops such as quinoa in crop systems (Çigdem et al., 2015). Quinoa development (Chenopodium quinoa Willd.) may contribute to food security in the developing world (Repo-Carrasco et al., 2003; Hirich et al., 2013) and was selected as one of the crops in the $21^{\text {st }}$ century to secure food (FAOSTAT, 2010; Ruiz et al., 2014). In order to preserve soil and water supplies, low-quality water (saline and drainage water) can be used for quinoa irrigation with an appropriate management strategy (Iqbal, 2015). Continued use of saline water with surface drip irrigation, however, can cause accumulation of salt near the soil surface (Hachicha et al., 2006) due to increased evaporation before migration and entering the main root zone, thereby adversely affecting crop growth and yield (Tingwu et al., 2003; Hanson et al., 2009; El Mokh et al., 2014). The result analysis performed on quinoa seed yield in response to multiple degrees of water stress applied during vegetative growth showed a very significant difference. During the vegetative growth period, applying 50 percent of the water requirements led to the highest seed yield, while applying 25 percent of the water requirements led to the lowest seed yield. The application of water stress during the time of vegetative growth mediated the development of the root system for quinoa (Geerts et al., 2005; Jacobsen et al., 2012). According to Hirich et al. (2014), $50 \%$ of water requirements treatments during the seed filling stage reported low yield compared to other water-stressed during vegetative growth and quinoa flowering period. Humic acid can boost soils that are impaired by salinity because of its benefits to shoot and root growth and also because of nutrient uptake of vegetable crops. Humic compounds make up a large part of organic matter. Studies have shown that adding humic acid to saline soil significantly reduced soil electrical conductivity and also increased plant nutrient absorption increased plant root and growth by allowing nutrients and water to be released into the plant as required (Canellas and Olivares 2014; Olivares et al., 2017). In addition, the applied humic acids have played a significant role in increasing soil property values (e.g. bulk density, porosity, available water, $\mathrm{pH}$, available nutrients, and hydraulic conductivity). Humic acid may be effective in vegetable growth in soil conditioners, improving crop tolerance, and saline growth conditions (Adil et al., 2011; Osman and Ewees, 2008). Because of the water crisis and the risks of soil degradation in irrigated areas, strategies need to be established which can help to conserve water and reduce salinity. Therefore, two irrigation systems and separate irrigation deficiency methods will be applied to the quinoa crop with the use of humic acid. The first objective of this study was to determine which water salinity level with low-quality soil can be used without any negative impact on yield (an initial experiment). The second objective was to determine the effects of drip irrigation (surface and subsurface) and irrigation regimes with a salinity level (according to the initial experimental results) on soil salinity, yield, and water use efficiency of quinoa under the arid conditions of Egypt. 


\section{MATERIALS AND METHODS}

In order to achieve the objectives of this research, an initial experiment on pots was performed during the 2017 winter season to assess the impact of water quality on quinoa crop productivity (fresh water $\left(0.45 \mathrm{dSm}^{-1}\right)$, ground water $\left(2.8 \mathrm{dSm}^{-1}\right)$ and saline water $\left(5\right.$ and $\left.7 \mathrm{dSm}^{-1}\right)$ ). The saline water for this experiment was prepared according to different ion content ( $\mathrm{NaCl}, \mathrm{MgSO} 4$, and CaSO4 2:2:1 mass ratio) as defined by Wang et al. (2016). Twenty pots with a volume of 25 liters $(25 \mathrm{~cm}$ diameter and $50 \mathrm{~cm}$ height $)$ were filled with experimental site soil and one seed /pot was planted with quinoa seeds. With $100 \%$ water requirements, both pots were irrigated. The results of this experiment lead to knowing which degree of salinity of water with the soil of low quality can be used without a negative impact on yield.

During the 2017-2018 and 2018-2019 winter seasons, two years field experiment was performed at the Experimental Farm of Agriculture Faculty, Qalyobia Governorate, Egypt, $\left(30^{\circ} 21^{\prime} \mathrm{E}, 31^{\circ} 13^{\prime} \mathrm{N} ; 17 \mathrm{~m}\right.$ above sea level). The growing season for quinoa extends for 100 days from October to January. The dominant soil of the experimental site was clay textured throughout the profile (1.62\% coarse sand, $21.12 \%$ fine sand, $28.04 \%$ silt, and $49.22 \%$ clay). The field capacity, wilting point, and electrical conductivity values were $37 \%, 18.2 \%$ and 3.1 $\mathrm{dSm}^{-1}$ respectively. The region is characterized by arid with total $22 \mathrm{~mm}$ rainfall and medium temperature, humidity and evaporation.

Two drip irrigation systems (surface and subsurface drip irrigation) were used. Polyethylene laterals of $16 \mathrm{~mm}$ diameter with built-in drippers of $4 \mathrm{lh}^{-1}$ at $30 \mathrm{~cm}$ apart were used with spacing of $0.7 \mathrm{~m}$. The $0.7 \mathrm{~m}$ spaced subsurface drip lines were buried in each row at a depth of $15 \mathrm{~cm}$ below the surface of the soil. The lateral inlet valve had average operating pressure of 1.0 bar. Three irrigation regimes have been implemented to irrigate the crop of quinoa, i.e. full irrigation at $100 \%$ crop evapotranspiration (ETc), $80 \%$ ETc and 60\% ETc for both surface and subsurface drip irrigation.

Humic acid is mainly used as a soil conditioner that has irrigation water added to the soil. Humic acid (93.5\%, Alpha Chemika, Mumbai, India) was used at 0 and $50 \mathrm{mgl}^{-1}$ and applied to the experimental soil mixed with irrigation by drip irrigation system for 2 months following transplantation as suggested (El-Hefny, 2010). The ETo was determined using Penman Monteith formula (Allen $\boldsymbol{e t}$ al., 1998) by using the climate data exported from weather station located near the site of the experiment. In addition, crop evapotranspiration (ETc= Kc . ETo) was determined using the crop coefficient $(\mathrm{Kc})$ for the different growth stages of quinoa according to Garcia et al. (2003) (0.52, 1.0 and 0.7 for initial, maximum canopy cover and physiological maturity). Net irrigation requirements were calculated using daily data from ETc, and adapted to the irrigation level.

The experimental design was split- split plot design as the main plots were for irrigation systems, while the submain plots were for deficit irrigation treatments and sub-submain were for with and without humic acid.

Moisture meter (HH2 with WET-2 sensor model, Delta-T, Cambridge, England) monitored the daily soil moisture content to show and monitor changes in soil moisture after irrigation till the next. Gravimetric moisture calculated the soil water content before and after the irrigations, which was determined by measuring the proportion of water loss relative to dry soil weight after the soil samples were oven-dried. Soil pH (pH meter: JENCO 1671 Model, USA, 0.1 
accuracies) and EC (EC Meter: ORION 105 Model, USA, 0 to $199.99 \mathrm{dSm}^{-1}$, and $0.5 \%$ accuracy) were calculated in 1:5 soil, water suspension in soil paste extract for each gravimetric soil sample at the beginning, middle and end of the growing seasons. In plants, the chlorophyll ratio (Chlorophyll meter: SPAD 502 Plus System, Germany) was determined at flowering. Quinoa (Chenopodium quinoa Willd.) seeds were planted by hand in two seasons (mid-October 2017 and 2018) at a distance of $30 \mathrm{~cm}$ on one side of the furrow (12 $\mathrm{m}$ long and $0.70 \mathrm{~m}$ broad). The plot was made of 3 furrows. All other agricultural practical for quinoa crop was used as recommended by Benlhabib et al. (2015).

All treatments were irrigated with $20 \mathrm{~mm}\left(200 \mathrm{~m}^{3} \mathrm{ha}^{-1}\right)$ for the first stage ( 0 and 15 days after sowing), after that the $100 \%$ treatments received $111 \mathrm{~mm}\left(1110 \mathrm{~m}^{3} \mathrm{ha}^{-1}\right)$ of water, $80 \%$ of treatments received $88.8 \mathrm{~mm}\left(888 \mathrm{~m}^{3} \mathrm{ha}^{-1}\right)$ and the $60 \%$ of treatments received $66.6 \mathrm{~mm}(666$ $\left.\mathrm{m}^{3} \mathrm{ha}^{-1}\right)$ till the end of the growing season. The experiment received a quantity of rainwater (11 $\mathrm{mm})$ at the end of the first season and $(14 \mathrm{~mm})$ at the beginning of the last month of the second season.

The irrigation starts on all treatments when $75 \%$ of available water capacity of $100 \%$ ETc irrigation treatment is consumed. Ten plants were randomly selected from each treatment at flowering to measure plant height $(\mathrm{cm})$, number of branches a plant, and Chlorophyll ratio, while head length was measured before harvesting. At harvest, (100 days from planting) plants were harvested, and the total yield $\left(\mathrm{Mgha}^{-1}\right)$ was recorded as total weight of harvested seeds per treatment. Water use efficiency (WUE) is defined as the yield obtained per unit of water consumed. The WUE $\left(\mathrm{kgm}^{-3}\right)=$ Yield $\left(\mathrm{kgha}^{-1}\right) /$ total water received $\left(\mathrm{m}^{3} \mathrm{ha}^{-1}\right)$ from planting to harvest (El Mokh et al., 2014).

All data collected were analyzed statistically, as Snedcor and Cochran (1982) described. Means between treatments were compared at a probability of $\mathrm{P}<0.05$ using the Least Significant Difference (LSD).

\section{RESULTS AND DISCUSSION}

I. The initial experiment (Effect of water salinity levels on quinoa yield and yield components) Irrigation salinity had a significant effect on growth, yield components, and grain yield per plant. Values of plant height, the average number of branches/plant, length of head, and chlorophyll ratio were almost the same values when quinoa was irrigated with freshwater and moderate saline water $\left(2.8 \mathrm{dS} . \mathrm{m}^{-1}\right)$, but all of them were significantly higher than those plants irrigated with saline water treatments $\left(5\right.$ and $\left.7 \mathrm{dS} . \mathrm{m}^{-1}\right)$ as shown in Table (1). Similar trend and course of significance were observed in the case of grain yield. Results in Table (1) showed that the excesses in yield when quinoa was irrigated with freshwater and $2.8 \mathrm{dS} . \mathrm{m}^{-1}$ water over plants irrigated with saline water were estimated to be $68.2 \%$ and $97.2 \%$ for EC of 5 and 7 $\mathrm{dS} . \mathrm{m}^{-1}$ treatments, respectively. The analysis of data also indicated that all the studied yield components have had a pronounced effect on the grain yield/plant as influenced by water salinity. The same trend was obtained by Algosaibi et al. (2015). This indicates that the plant can tolerate salinity of up to $3 \mathrm{dS} \cdot \mathrm{m}^{-1}$ without affecting its productivity, but if the salinity exceeds that, it leads to influence on some traits of growth and production. From here it was excluded the use of saltwater ( 5 and $7 \mathrm{dS} . \mathrm{m}^{-1}$ ) in the main experiment and only using groundwater $\left(2.8 \mathrm{dS} . \mathrm{m}^{-1}\right)$ to measure the effect of drip irrigation systems and water stress with and without humic acid on quinoa productivity. 
Table (1): Effect of water salinity levels on mean yield and components of yield for quinoa

\begin{tabular}{|l|c|c|c|c|c|}
\hline \hline Treatments & $\begin{array}{c}\text { Plant } \\
\text { Height, Cm }\end{array}$ & $\begin{array}{c}\text { Branches } \\
\text { No. }\end{array}$ & $\begin{array}{c}\text { Head } \\
\text { length cm }\end{array}$ & $\begin{array}{c}\text { Chlorophyll } \\
\text { ratio }\end{array}$ & $\begin{array}{c}\text { Yield } \\
\text { g/plant }\end{array}$ \\
\hline \hline Control & $105.3^{\mathrm{a}}$ & $14.7^{\mathrm{a}}$ & $22.7^{\mathrm{a}}$ & $58.2^{\mathrm{a}}$ & $56.2^{\mathrm{a}}$ \\
\hline $2.8 \mathrm{EC}$ & $104.0^{\mathrm{a}}$ & $14.7^{\mathrm{a}}$ & $21.8^{\mathrm{a}}$ & $57.2^{\mathrm{a}}$ & $55.8^{\mathrm{a}}$ \\
\hline $5 \mathrm{EC}$ & $78.0^{\mathrm{b}}$ & $12.5^{\mathrm{b}}$ & $15.0^{\mathrm{b}}$ & $45.4^{\mathrm{b}}$ & $33.3^{\mathrm{b}}$ \\
\hline $7 \mathrm{EC}$ & $61.7^{\mathrm{c}}$ & $10.1^{\mathrm{c}}$ & $11.7^{\mathrm{c}}$ & $41.1^{\mathrm{b}}$ & $28.4^{\mathrm{c}}$ \\
\hline LSD $_{0.005}$ & 14.2 & 1.03 & 3.6 & 7.12 & 7.7 \\
\hline \hline
\end{tabular}

\section{The main experiment}

1. Effect of irrigation system, water regimes and humic acid on soil water content, salinity and $\mathrm{pH}$ Generally, Soil water contents were low on surface than subsurface drip irrigation by 6.2 and $2.03 \%$ for both before and after irrigation, respectively. This trend could be because of water evaporation from the surface and hence decreased soil water content in the surface layer especially for the surface drip system more than the subsurface drip system.

The average of soil moisture content before irrigation ranged from $20.5 \%$ for $60 \% \mathrm{ETc}$ to $24.6 \%$ for $100 \% \mathrm{ETc}+$ humic under surface drip irrigation (Fig. 1A) while, it ranged from $21.5 \%$ to $26.9 \%$ for $60 \%$ ETc and $100 \% \mathrm{ETc}+$ humic respectively, under subsurface drip treatments (Fig. 1C). After irrigation, the average of SMC ranged from $31.5 \%$ to $38.4 \%$ under surface drip (Fig. 1B) and $32.4 \%$ to $38.7 \%$ under subsurface drip (Fig. 1D) for $60 \%$ ETc and $100 \%$ ETc + humic respectively.

As shown, the full irrigation rate showed relatively high soil water content along with the soil profile followed by $80 \%$ ETc and it was more pronounced in the humic treatments. Where the rates were illustrated between the field capacity and the allowed minimum moisture content line (after $75 \%$ of ETc is consumed) except $60 \%$ ETc treatments, the SMC was illustrated under the allowed minimum moisture content line especially during the flowering and harvesting stages. Similar data were obtained by Malash et al. (2008) and Pulvento et al. (2013).

Soil salinity values in the root zone $(0-60 \mathrm{~cm})$, expressed by the EC, under different irrigation treatments for surface and subsurface drip irrigation methods at planting, development, flowering, and harvest stages are presented in Fig. (2). The average soil salinity value determined at planting was $3.1 \mathrm{dSm}^{-1}$ in both two seasons. The results show a decrease in EC values measured at mid-season and harvest is observed under all irrigation treatments and methods compared to initial soil salinity. The EC values are lower in the case of humic than without humic treatments.

For both irrigation methods, full irrigation $(100 \%$ and $100 \%+\mathrm{H})$ resulted in a significantly lower EC value than with deficit irrigation treatments at harvesting. The EC values between development and harvest decreased with 8.2, 7.2, and 6.5\% and decreased with 10.6, 10.3, and $8.1 \%$ for $100 \%, 80 \%$, and $60 \%$ ETc without and with humic treatments, respectively under surface drip system. While the reduction in EC was higher under the subsurface drip system between development and harvest. EC decreased with 9.7, 7.9, and 7.3\%, and decreased with $12.9,11.9$ and $11.1 \%$ for $100 \%, 80 \%$, and $60 \%$ ETc without and with humic treatments, respectively. As mentioned in the materials and methods, the reduction in soil EC values at the end of season less than EC of irrigation water may be due to the rainfall at the last month of both seasons (11 and $14 \mathrm{~mm}$ ) that leached some salts. 


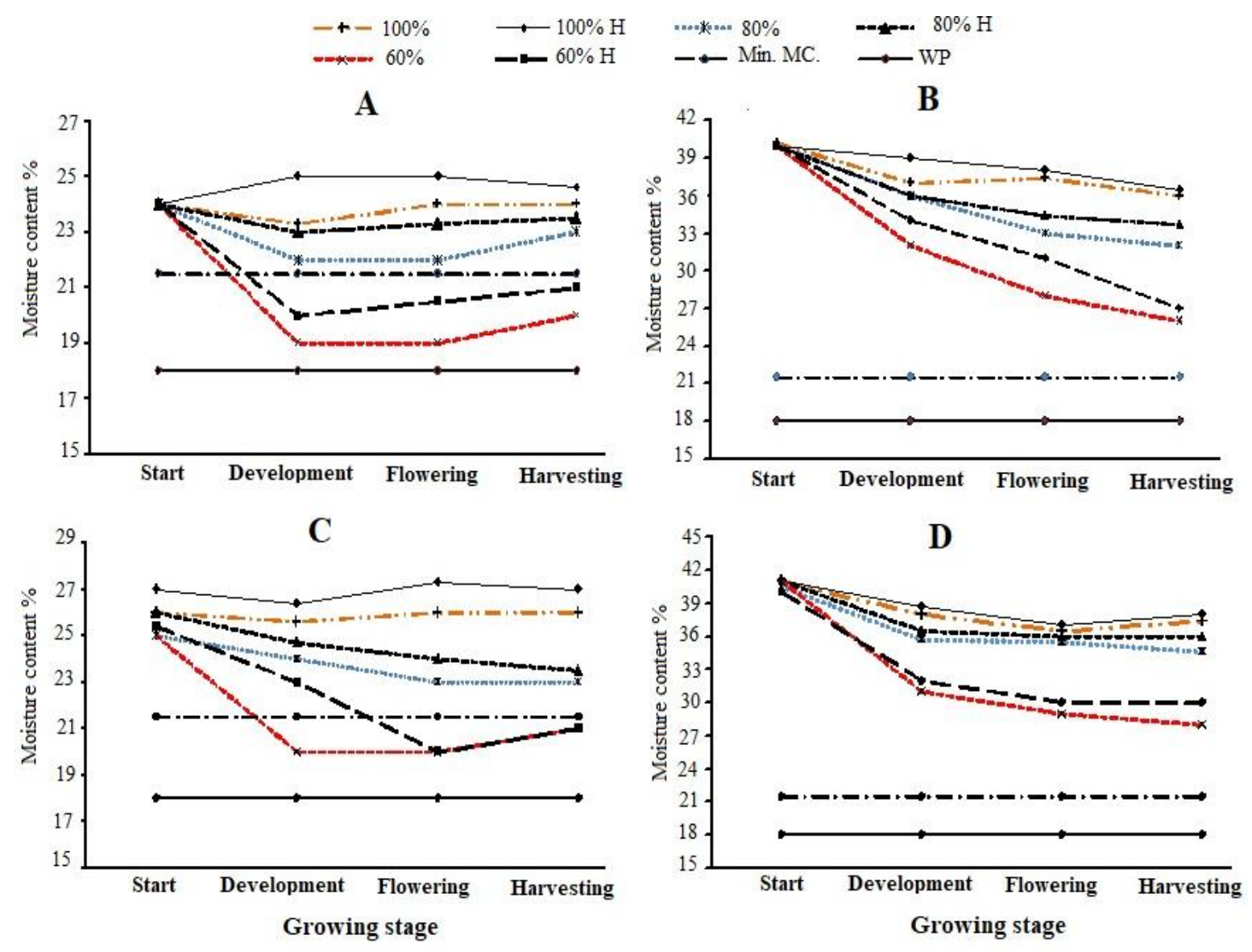

Fig (1): Effect of irrigation system, water regimes, and humic acid on soil moisture content [Surface drip A (before irrigation) and B (after irrigation), Subsurface drip C (before irrigation) and $D$ (after irrigation)]
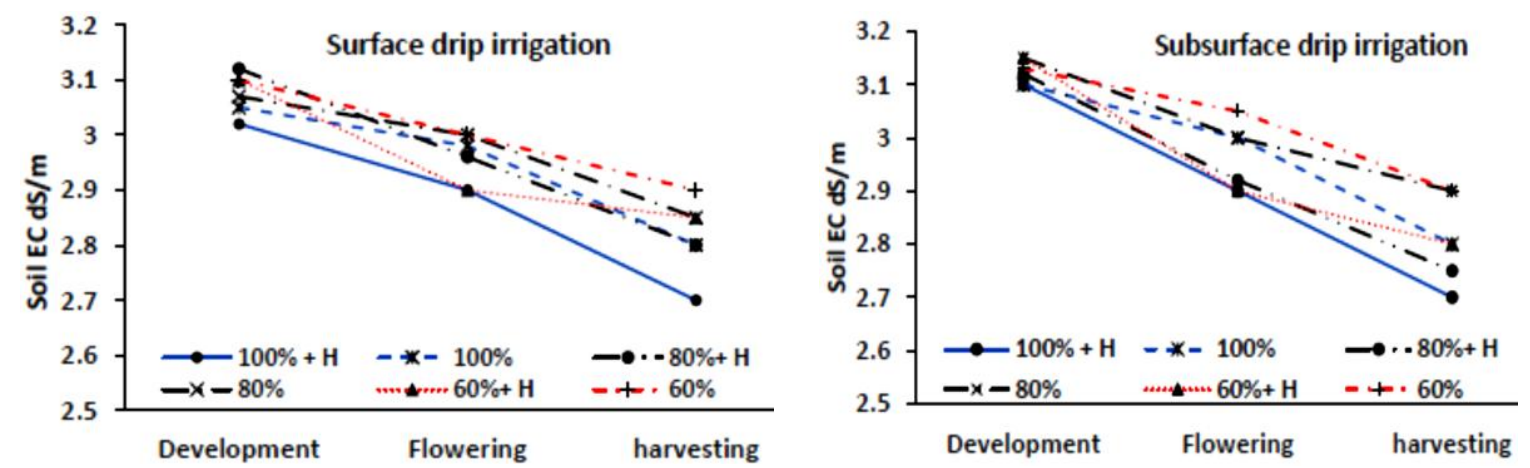

Fig (2): Effect of irrigation system, water regimes, and humic acid on soil salinity

The soil salinity also exhibits trends similar to that of the soil moisture content. The difference observed between irrigation methods (surface and subsurface) is mainly because of the difference in soil moisture content since the irrigation water supplies were similar. These results are in close agreement with those of Oron et al. (2002) who indicated that soil salinity with subsurface drip irrigation is lower than that with surface drip irrigation. According to the soil moisture content values for each irrigation method, it can be concluded that the SSDI keeps higher moisture content in the root zone which may lead to continuous leaching of accumulated salts and thus reduce the soil salinity values (Abdulrasoul et al., 2010). Also, this effect may be attributed to the fact that humic acid became absorbed many times their weight of water 
which diluted the salt effect and store it for a relatively long period of time as reported by Aydin et al. (2012). Humic acid may stimulate plant growth, improve resistance to environmental stress in plants, and mitigate the salinity effect in strawberry seedlings in salty conditions (Ekin, 2019).

Figure (3) illustrates the effect of irrigation systems, water regimes, and humic treatments on soil $\mathrm{pH}$ during the different growing stages of quinoa. As shown, there is no effect of irrigation systems (surface and subsurface irrigation) as well as irrigation regimes, where the $\mathrm{pH}$ values almost the same between the development and harvest stage. Only, the humic treatments showed a significant reduction in $\mathrm{pH}$ values. The $\mathrm{pH}$ decreased with $9,8.7$ and $7.3 \%$, and decreased with $8.9,8.6$, and $7.5 \%$ for $100 \%, 80 \%$, and $60 \%$ ETc with humic treatments, under surface and subsurface irrigation systems, respectively. As noticed, there are no differences between $\mathrm{pH}$ values under irrigation systems, while there are differences between irrigation regimes because of the humic acid quantity that applied with the irrigation. This result may be due to the role of acidity of humic acid which changes the $\mathrm{pH}$ of soil. Humic acid is also a sequestering compound which allows it to break the bond between Sodium and Magnesium, therefore allowing the Sodium to leach from the soil's profile as reported by El-Hefny (2010).
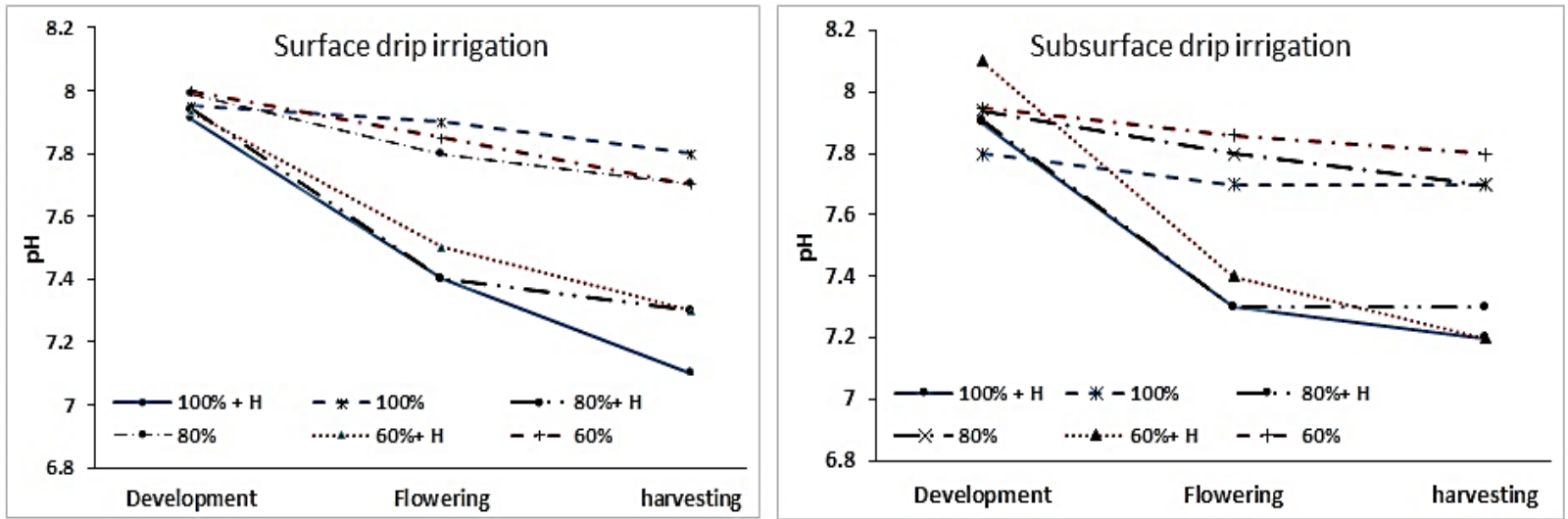

Fig (3): Effect of irrigation system, water regimes and humic acid on soil pH

2. Effect of irrigation system, water regimes, and humic acid on yield, and yield components

Results in Table (2) revealed that quinoa growth, yield components, and irrigation system, water regimes, and humic acid affected yield. The result evidenced that plant height and branches per plant slightly increased under SSD than SD system but with insignificant differences, while the differences were clear enough to reach the 5\% level of significance for head length, chlorophyll ratio, and yield. The mean yield was $0.12 \mathrm{Mg} / \mathrm{ha}$ under SSD more than SD system. Water stress significantly affected all yield components except chlorophyll ratio. There were no significant differences between $100 \%$ and $80 \%$ ETc while it recorded the lowest values of yield components for $60 \%$ ETc as shown in Table (2). Regarding the yield, the higher grain yield was noticed for $80 \%$ ETc than $100 \%$ ETc with an increase of $0.9 \%$ (not significant) and $60 \%$ ETc with an increase of $40.3 \%$ (high significant differences).

The effect of humic acid results indicated clearly that there was a significant effect on some growth behavior traits of quinoa i.e. plant height, head length, and yield, while there is no significant effect on branches, and chlorophyll ration. The plant height, head length and yield values were increased with $6.21 \%, 8.3 \%$ and $5.9 \%$, respectively by using humic acid with irrigation. The interaction between irrigation systems and water regimes as shown in Tables (2) 
did not show a significant effect on all measured parameters for $100 \%$ and $80 \%$ ETc water regimes under both irrigation systems, while indicated a significant increase for all measured parameters except chlorophyll ratio under SSD with 80\% ETc compared with $60 \%$ ETc.

Table (2): Effect of irrigation system, water regimes and humic acid on quinoa yield and yield components

\begin{tabular}{|c|c|c|c|c|c|c|c|}
\hline $\begin{array}{l}\text { Irri. } \\
\text { system }\end{array}$ & $\begin{array}{l}\text { Water } \\
\text { stress }\end{array}$ & $\begin{array}{c}\text { Humic } \\
\mathrm{mgl}^{-1}\end{array}$ & $\begin{array}{c}\text { Height } \\
\text { cm }\end{array}$ & $\begin{array}{c}\text { No. of } \\
\text { Branches }\end{array}$ & $\begin{array}{c}\text { Head } \\
\text { length } \\
\text { cm }\end{array}$ & Chlorophyll & Yield \\
\hline \multirow{9}{*}{ SD } & \multirow{3}{*}{$\begin{array}{l}100 \% \\
\text { ETc }\end{array}$} & 0 & 104.0 & 14.7 & 21.7 & 56.7 & 3.94 \\
\hline & & 50 & 112.3 & 15.0 & 23.3 & 57.0 & 4.03 \\
\hline & & Mean & 108.2 & 14.9 & 22.5 & 56.9 & 4.0 \\
\hline & \multirow{3}{*}{$\begin{array}{l}80 \% \\
\text { ETc }\end{array}$} & 0 & 108.7 & 15.9 & 23.7 & 56.7 & 3.95 \\
\hline & & 50 & 110.7 & 16.1 & 24.0 & 59.7 & 4.08 \\
\hline & & Mean & 109.7 & 16.0 & 23.9 & 58.2 & 4.02 \\
\hline & \multirow{3}{*}{$\begin{array}{l}60 \% \\
\text { ETc }\end{array}$} & 0 & 89.3 & 13.3 & 18.7 & 55.0 & 2.15 \\
\hline & & 50 & 91.7 & 14.3 & 21.3 & 57.4 & 2.44 \\
\hline & & Mean & 90.5 & 13.8 & 20.0 & 56.2 & 2.30 \\
\hline \multicolumn{3}{|c|}{ Mean } & 102.8 & 14.9 & 22.1 & 57.1 & 3.43 \\
\hline \multirow{9}{*}{ SSD } & \multirow{3}{*}{$\begin{array}{l}100 \% \\
\text { ETc }\end{array}$} & 0 & 107.3 & 15.0 & 24.7 & 55.1 & 4.01 \\
\hline & & 50 & 121.7 & 16.3 & 27.3 & 65.8 & 4.09 \\
\hline & & Mean & 114.5 & 15.7 & 26.0 & 60.5 & 4.05 \\
\hline & \multirow{3}{*}{$\begin{array}{l}80 \% \\
\text { ETc }\end{array}$} & 0 & 116.0 & 16.7 & 25.3 & 56.4 & 4.05 \\
\hline & & 50 & 121.3 & 17.7 & 28.7 & 59.3 & 4.17 \\
\hline & & Mean & 118.7 & 17.2 & 27.0 & 57.9 & 4.11 \\
\hline & \multirow{3}{*}{$\begin{array}{l}60 \% \\
\text { ETc }\end{array}$} & 0 & 102.7 & 14.3 & 22.7 & 55.1 & 2.35 \\
\hline & & 50 & 109.3 & 14.7 & 23.7 & 58.8 & 2.62 \\
\hline & & Mean & 106.0 & 14.5 & 23.2 & 57.0 & 2.49 \\
\hline \multicolumn{3}{|c|}{ Mean } & 113.1 & 15.8 & 25.4 & 58.4 & 3.55 \\
\hline \multirow{7}{*}{$\begin{array}{l}\text { LSD } \\
0.05\end{array}$} & \multirow{7}{*}{\multicolumn{2}{|c|}{$\begin{array}{l}\text { Irri. Sys. (IS } \\
\text { Water Stres } \\
\text { ISxWS } \\
\text { Humic (H) } \\
\text { ISxH } \\
\text { WSxH } \\
\text { ISxWSxH }\end{array}$}} & n.s & n.s & 3.052 & 1.522 & 0.11 \\
\hline & & & 7.389 & 1.064 & 1.16 & n.s & 0.042 \\
\hline & & & 10.45 & 1.51 & 1.64 & n.s & 0.059 \\
\hline & & & 5.35 & n.s & 0.91 & n.s & 0.032 \\
\hline & & & 7.57 & 1.47 & 1.28 & n.s & 1.046 \\
\hline & & & 9.28 & 1.81 & 1.57 & n.s & 0.563 \\
\hline & & & 13.12 & 2.55 & 2.22 & 9.79 & 0.8 \\
\hline
\end{tabular}

The interaction between irrigation systems and humic acid as well as between irrigation regimes and humic acid gave the same trend of interaction between irrigation systems and water regimes. The data indicated that the combined effect of SSD statistically influenced positively the values of plant height, a number of branches, head length, chlorophyll ration, and yield with $80 \% \mathrm{ETc}$ and application humic acid $\left(50 \mathrm{mgl}^{-1}\right)$. These favorable results may be due to the role of humic acid as a nutrient supplying that increase the availability of nutrient elements which consequently increased the vegetative growth of plant i.e., plant height, number of branches/plants, head length and the chlorophyll ratio as reported by Ekin (2019). In the same respect, El-Desuki (2004) and Abd El- Al et al. (2005) on onion plants found that humic acid application caused an improvement in plant vegetative growth.

It is obvious from Fig. (4) that WUE $\left(\mathrm{kgm}^{-3}\right)$ was lower in plots that got 60\% ETc water regime due to the reduction in the yield (average of 2.65 and $2.86 \mathrm{kgm}^{-3}$ for SD and SSD, respectively) followed by $100 \%$ ETc water regime (average of 3.04 and $3.09 \mathrm{kgm}^{-3}$ for SD and SSD, respectively). On the other hand, the highest values for WUE were accounted for regarding 
$80 \%$ ETc water regime (average of 3.69 and $3.78 \mathrm{kgm}^{-3}$ for SD and SSD, respectively) due to the higher productivity with $20 \%$ water requirement lower than $100 \%$ ETc treatments. As shown humic acid affected the WUE but with no significant increases. These results agreed with those obtained by Hirich et al. (2014).

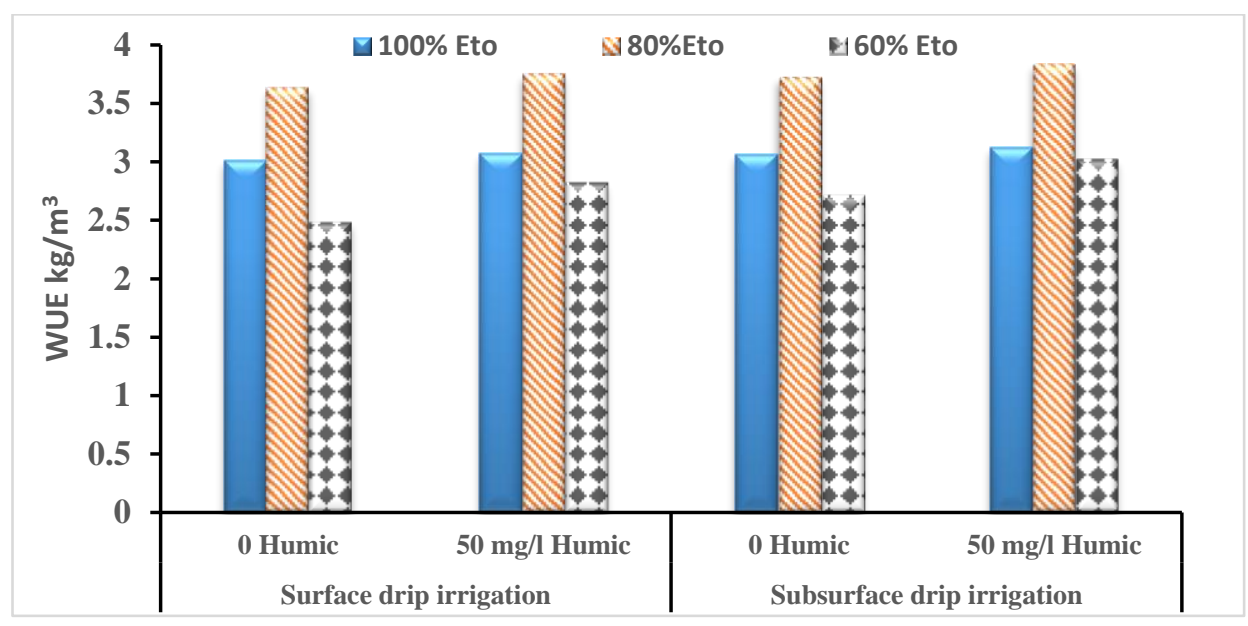

Fig. (4): Water productivity as affected by irrigation system, water regimes and humic treatments

\section{CONCLUSION}

Drought and salinity are widespread environmental problems resulting from climate change and unsound applications in agriculture and have significant adverse effects on agricultural production. To sustain productivity in such areas for food security, growing new crops that can grow under these unsuitable conditions is one measure. Two field experiments were conducted on clayey soil with inferior quality $\left(3.1 \mathrm{dSm}^{-1}\right)$ in the southern Nile Delta of Egypt. Results showed that the yield was significantly affected by using saline water ( 5 and $7 \mathrm{dSm}^{-1}$ ) where it decreased by 40.7 and $49.5 \%$ respectively, compared with freshwater, while there were no differences between fresh and groundwater. From here it was excluded the use of saltwater ( 5 and $\left.7 \mathrm{dS} . \mathrm{m}^{-1}\right)$ in the main experiment and only using groundwater $\left(2.8 \mathrm{dSm}^{-1}\right)$ to measure the effect of surface drip and subsurface drip irrigation methods with three irrigation regimes $\left(100 \%, 80 \%\right.$ and $60 \%$ of irrigation requirements) and humic acid $\left(0\right.$ and $\left.50 \mathrm{mgl}^{-1}\right)$ on soil moisture and salinity, yield and water productivity of quinoa. The results indicated that using ground water to irrigate quinoa with SSDI, $80 \%$ water stress and $50 \mathrm{mgl}^{-1}$ humic acid improved soil salinity, $\mathrm{pH}$ and moisture content. These favorable conditions of the improved soil reflected on the vegetative growth parameters of quinoa (i.e., plant height, number of branches/plant, head length and the chlorophyll ratio) and showed significant increases in seed yield (4.17 $\left.\mathrm{Mgha}^{-1}\right)$ and water productivity $\left(3.78 \mathrm{kgm}^{-3}\right)$ with $20 \%$ of water-saving.

\section{REFERENCES}

Abd E1-Al, S., et al. (2005) 'Response of growth and yield of onion plants to potassium fertilizer and humic acid' J. Agric. Sci. Mansoura Univ., 30(1): 441-452.

Abdulrasoul, M., et al. (2010) 'Impact of irrigation water quality, irrigation systems, irrigation rates and soil amendments on tomato production in sandy calcareous soil' Turk. J. Agric. For., 34: 59-73, http://dx.doi.org/10.3906/tar-0902-22 
Adil, A., Canan, K. and Metin, T. (2011) 'Humic acid application alleviates salinity stress of bean (Phaseolus vulgaris L.) plants decreasing membrane leakage’ African J. of Agric. Res. 7(7): 1073-1086, http://dx.doi.org/10.5897/AJAR10.274

Ahmed, S., Shalaby, A. and Mokhtar, A. (2018) 'Influence of deficit irrigation using saline water on yield of tomato under two irrigation systems' Alexandria Sci. EXCH. J., 39 (1).

Algosaibi, A., et al. (2015) 'Effect of irrigation water salinity on the growth of quinoa plant seedlings' J. of Agric. Sci., 7 (8). http://dx.doi.org/10.5539/jas.v7n8p205

Allen, G., et al. (1998) 'In Crop evapotranspiration - guidelines for computing crop water requirements-FAO Irrigation and drainage paper 56, FAO, Rome, 300(9), D05109.

Aydin, A., Kant, C. and Turan, M. (2012) 'Humic acid application alleviate salinity stress of bean (Phaseolus vulgaris L.) plants decreasing membrane leakage'. African Journal of Agricultural Research. 7(7): 1073-1086, http://dx.doi.org/10.5897/AJAR10.274

Benlhabib, O., et al. (2015) 'In State-of-the-Art report of quinoa in the world'. Chapter 6.1.5: Status of quinoa production and research in Morocco. Rome: FAO and CIRAD.

Canellas, P. and Olivares, L. (2014) 'Physiological responses to humic substances as plant growth promoter'. Chem. Bio. Tech. Agric. 1 (3)

Çigdem, K., Attila, Y. and Sezen, M. (2015) 'SALTMED model performance on simulation of soil moisture and crop yield for quinoa irrigated using different irrigation systems, irrigation strategies and water qualities in Turkey'. Agriculture and Agricultural Science Procedia (4): $108-118$.

Ekin, Z. (2019) 'Integrated use of humic acid and plant growth promoting rhizobacteria to ensure higher potato productivity in sustainable agriculture'. Sustainability, 11, 3417; http://dx.doi.org/10.3390/su11123417

EL Mokh, F., et al. (2014) 'Effects of surface and subsurface drip irrigation regimes with saline water on yield and water use efficiency of potato in arid conditions of Tunisia'. J. of Agric. and Envir. for Int. Dev., $108 \quad$ (2): 227 - 246. http://dx.doi.org/10.12895/jaeid.20142.258.

El-Desuki, M. (2004) 'Response of onion plants to humic acid and mineral fertilizers application'. Annals of Agric. Sci., Moshtohor, 42(4): 1955-1964.

El-Hefny, E. (2010) 'Effect of saline irrigation water and humic acid application on growth and productivity of two cultivars of cowpea (Vigna unguiculata L. Walp)'. Australian J. of Basic and App. Sci., 4(12): 6154-6168.

FAOSTAT (2010) Agriculture production. Food and Agriculture Organization of the United Nations.

Garcia, M., Raes, D. and Jacobsen, E. (2003) 'Evapotranspiration analysis and irrigation requirements of quinoa (Chenopodium quinoa Willd) in the Bolivian highlands'. Agric. Wat. Manag., 60 (2): 119-134

Geerts, S., et al. (2005) Response of quinoa (Chenopodium quinoa) to differential drought stress in the Bolivian altiplano: towards a deficit irrigation strategy within a water scarce region. PhD thesis. Leuven, Belgium, Faculty of Bioscience Engineering Laboratory for Soil and Water Management. 
Hachicha, M., Nahdi, H. and Rejeb, S. (2006) 'Effet de l'irrigation au goutte à goutte outerraine avec l'eau salée sur une culture de piment'. Ann. INRAT. 79, 85-103.

Hanson, R., et al. (2009) 'Drip irrigation provides the salinity control needed for profitable irrigation of tomatoes in the San Joaquin Valley'. California Agric. 63(3): 131-136.

Hirich, A., Choukr-Allah, R. and Jacobsen, E. (2013) 'The combined effect of deficit irrigation by treated wastewater and organic amendment on quinoa (Chenopodium quinoa Willd.) productivity'. Desalin Water Treat:1-6.

Hirich, A., et al. (2014) 'Using deficit irrigation to improve crop water productivity of sweet corn, chickpea, faba bean and quinoa: a synthesis of several field trials'. Rev. Mar. Sci. Agron. Vét. 2 (1):15-22

Iqpal, M. (2015) 'An assessment of quinoa (Chenopodium quinoa Willd.) potential as a grain crop on marginal lands in Pakistan'. American-Eurasian J. Agric. and Environ. Sci., 15 (1): 16-23. http://dx.doi.org/10.5829/idosi.aejaes.2015.15.1.12474

Jacobsen, E., Jensen, R. and Liu, F. (2012) 'Improving crop production in the arid Mediterranean climate'. Field Crop Res. 128: 34-47.

Malash, M., Flowers, J. and Ragab, R. (2008) 'Effect of irrigation methods, management and salinity of irrigation water on tomato yield, soil moisture and salinity distribution'. Irrig Sci 26: 313-323.

Olivares, L., et al. (2017) 'Plant growth promoting bacteria and humic substances: Crop promotion and mechanisms of action'. Chem. Biol. Technol. Agric., 4 (3).

Oron, G., et al. (2002) 'Effect of water salinity and irrigation technology on yield and quality of pears'. Biosyst. Eng. 81, 237-247.

Osman, H. and Ewees, A. (2008) 'The possible use of humic acid incorporated with drip irrigation system to alleviate the harmful effects of saline water on tomato plants'. Fayoum J. Agric. Res. and Dev., 22 (1).

Pulvento, C., et al. (2013) 'SALTMED model to simulate yield and dry matter for quinoa crop and soil moisture content under different irrigation strategies in south Italy'. Irri. and drain. http://dx.doi.org/10.1002/ird.1727

Repo-Carrasco, R., Espinoza, C. and Jacobsen, E. (2003) 'Nutritional value and use of the Andean crops quinoa (Chenopodium quinoa and Chenopodium pallidicaule)'. Food Rev. Int., 19(1-2): 179-189.

Ruiz, B., et al. (2014) 'Quinoa biodiversity and sustainability for food security under climate change’. A Review. Agro. for Sust. Dev., 34: 349-359.

Snedcor, W. and Cochran, G. (1982) Statistical methods. 7th Ed, The Iowa State University Press, Iowa.

Tingwu, L., et al. (2003) 'Effect of drip irrigation with saline water on water use efficiency and quality of watermelons'. Water Resources Management. 17(6), 395-408.

Wang, Q., et al. (2016) 'Impact of saline water irrigation on water use efficiency and soil salt accumulation for spring maize in arid regions of China'. Agric. Wat. Manag. 163: 125138. http://dx.doi.org/10.1016/j.agwat.2015.09.012

Yazar, A. and İNCE Kaya, Ç. (2014) 'A new crop for salt affected and dry agricultural areas of Turkey: Quinoa (Chenopodium quinoa Willd.)'. Turk. J. of Agric. and Nat. Sci. Special Issue: 2. 


\section{تأثير أنظمة الري والإجهاد المائي مع انذفاض جودة المياه والتربة على محصول الكينوا في الظروف الجافية

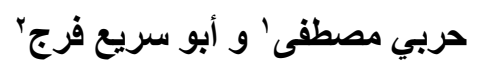

' أستاذ مساعد الهندسة الزر اعية ـ كلية الزر اعة ـ جامعة بنها ـ مصر.

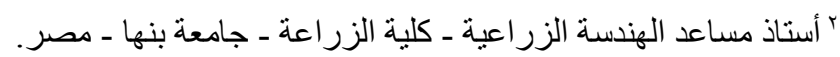

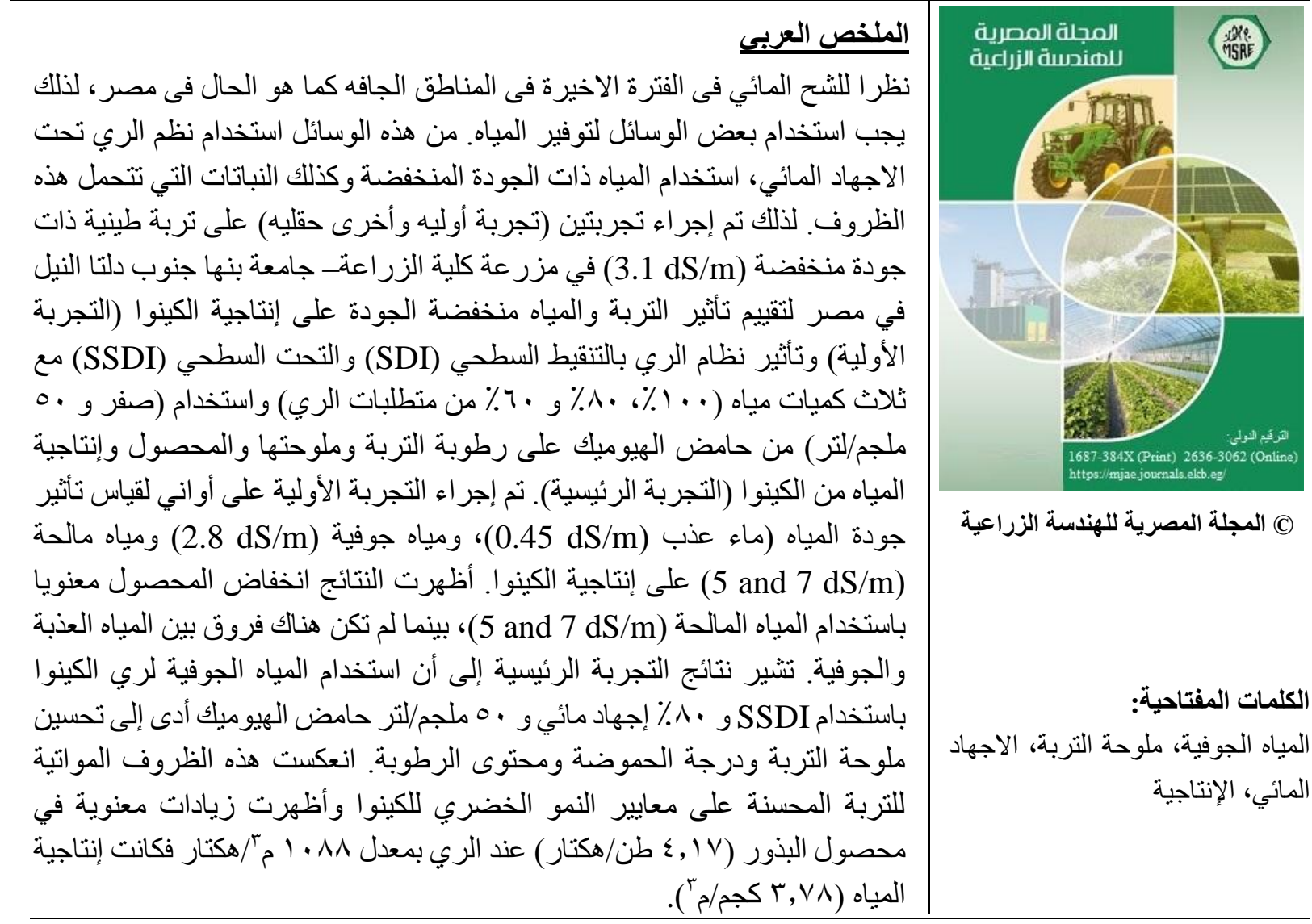

